\title{
Beyond Petrotoxic Apparatuses
}

\author{
Néstor L. Silva
}

ABSTRACT: Literature on petroleum and its toxicities understands both as simultaneously social and ecological. Beginning with scholarship on petroleum and its toxicity that captures that simultaneity and mutual constitution, this review defines petrotoxicity as the socioecological toxicity inherent in petroleum commodification. The term signals that petroleum's social and ecological toxicities are not merely related, but always/already interdependent and inherent in petroleum commodification. Thinking about petrotoxicity this way frames it as something similar to repressive and ideological apparatuses. Althusserian apparatuses shape subjects and spaces in violent and bureaucratic ways. Generating and resisting petrotoxic apparatuses are consistent themes of literature on petrotoxicity. Thinking with Stuart Hall's critique of Louis Althusser, this review concludes by highlighting scholarship showing the limits of this popular framing of power, ecology, and intervention vis-à-vis petroleum. Long-term fieldwork in North Dakota's Bakken region informs this article at various points.

KEYWORDS: Bakken, DAPL, North Dakota, oil, petroleum, pollution, toxicity

In 1901, the Village of Tioga was founded by settler-farmers in northwestern North Dakota. Fifty years later, marketable oil and gas were discovered on a farm a few miles southwest of town. The second producing well in the state was drilled just northeast of town on land owned by Norwegian homesteaders with the surname "Bakken." Their well discovered shale strata, which were later named for the family. That formation underlies much of northwestern North Dakota and is now the primary target of the state's contemporary fracking industry. Now, "Bakken" refers to the state's farmland and oilfield region.

Those juxtaposed land uses require negotiating the multiple toxicities that come with each step of oil commodification: exploration and infrastructure, drilling and fracking, extraction and shipping, refinement and consumption. This is to say, the toxic effects of the petroleum industry are familiar objects and targets of management by corporations, government, scientists, and the descendants of settlers all committed to maintaining the Bakken. They were my primary interlocutors during my 16 months of ethnographic fieldwork based in Tioga as I studied the environmental politics of the Bakken.

Today, the small rural municipality has around 2,000 permanent residents-almost exclusively White, conservative, and pro-oil-as well as a shifting population of itinerant hydrocarbon industry workers. I chose Tioga as a field site once I saw its official logo: a farmland well-site with horse-head pump-jack with a pipeline running along the ground, which had stalks of wheat and a radiant sun in the background: a sunny outlook on farmland petroleum extraction. Despite the petroleum-related social and ecological toxicity that was both salient and potential 
in the Bakken, the community of Tioga generally maintains that sunny outlook on hydrocarbon extraction, agriculture, and their intersection.

Scholarship often approaches the environmental politics of the petroleum industry by researching how communities and spaces come to be marginalized racially, economically, and politically. In Tioga, social conditions call into question the ubiquity of that paradigm of power and analysis. There, descendants of settlers work in the oil industry, own land, and/or own mineral rights. As opposed to being a place beset by marginalization, Tioga is a place where oil capitalism is culture, where managing environmental issues in the petroleum industry is preferable to denouncing them as forms of marginalization.

On farmland just outside of town in 2013, a lightning strike-according to state investigators-blew a quarter-sized hole in a pipeline from which over 850,000 gallons of oil spilled undetected into a wheat field. The landowners told me they never felt the need to make it a legal or media issue because they believed the State of North Dakota and the company that owns the pipeline reacted to the disaster in good faith, and showed a genuine will to improve pipeline safety.

In 2016-2017, about 250 miles southeast of Tioga, people occupied the banks of Lake Oahe on the Missouri River, just north of the Standing Rock Reservation's official boundary. They harbored no belief in the good faith of institutions supporting the Dakota Access Pipeline (DAPL). The self-defined "water protectors" of the Standing Rock movement came from across the United States and the world to support the Dakota, Nakota, and Lakota (DNL) Nations which started and led the movement to stop DAPL's installation beneath the Mni Sose-the Missouri River-a touchstone of cultural life and current primary water source for the DNL Nations which still live along the river (Estes 2019; Estes and Dhillon 2019; Gilio-Whitaker 2019; Whyte 2017).

I spent 13 days at the Oceti Sakowin camp, leaving in a closing procession organized by the camp's long-term occupants on 22 February 2017. Most people I met there refused to accept DAPL's presence on unceded Native American territory; refused to accept toxic risk from the half-a-million barrels of Bakken oil passing through DAPL daily; and refused to accept hydrocarbon infrastructure exacerbating climate change. These refusals, integral to the movement, evidence an understanding of petroleum commodification as socially and ecologically toxic.

The people who keep the Bakken running know that spills imperil the valued North Dakotan social and ecological practice that is farming. This is to say, the residents of the Bakken also recognize that the toxicities of hydrocarbons are social and ecological: an embodied, processual, and material simultaneity that I strive to capture in this article. Addressing scholarship that interrogates the commodification and socioecological toxicity of petroleum, I reference my fieldwork with pro-oil descendants of settlers and my shorter time with \#NoDAPL activists.

Relating ethnographic research to literature and arguments on petroleum's socioecological toxicity, I suggest, highlights an analytical pattern in the study and politics of petroleum. Seminal pieces of oil and energy scholarship from the interdisciplinary social sciences stress the importance of context in thinking about oil and energy (Coronil 1997; Karl 1997; Mitchell 2011; Nader and Beckerman 1978; Sawyer 2004; Watts 2004b, 2005; White 1943; Yergin 1990). How petroleum-related socioecological toxicity manifests in the Bakken and at Standing Rock makes them microcosms of modern "oil assemblages" (Watts 2012): the networks of institutions and people, objects, organisms, and space that constitute the petroleum industry. The remainder of this article describes how structural political economy plays a salient but incomplete role in scholarship on the environmental politics of petroleum assemblages. 


\section{Defining Petrotoxicity}

Perhaps the most extensive scholarship on petrotoxicity comes from a dissertation on Francoist politics as a precursor to modern neoliberalism in Spain. Analyzing that country's reliance since the mid-twentieth century on petrochemicals for energy and synthetics integral to national identity and economy, but also to national affect, to bodies, and to the body politic, Ibai Atutxa (2018) identifies limited usage of the term petrotoxicity in recent published scholarship (Bessire and Bond 2014; Haraway 2016) and unpublished scholarship (but see also Romero 2016). In all cases, the term refers to "the toxicity of petroleum and elements that derive from it" (Atutxa 2018: 1), to the way "hydrocarbon problems" make "the conditions of [modern] life visible, factual, and politically operable" (Bessire and Bond 2014: 447). My usage builds on this definition.

Petrotoxicity evokes themes of power and capital, environment and embodiment, suggesting how contamination is not spatially bounded, temporally linear, or materially specific (Roberts 2017). Instead, the term suggests the ubiquity of petroleum and toxicity (Nading 2020). Hannah Appel and colleagues (2015) synoptically argue that the social science of petroleum commodification relies on common metonyms: "Oil is money or modernity or violence or social imaginary, but rarely appears as itself, or in its conditions of technosocial possibility" (2015: 17-18). Petrotoxicity refers to such conditions of possibility, to the suite of toxic social and ecological effects generated and required to commodify petroleum: its pernicious capture and exchange; its noxious effects on bodies and the body politic; and the ever-present and evermore-unmanageable ecological degradation that petroleum inspires across various sites and scales.

Understanding petroleum's socioecological toxicities begins with awareness of its biological origins, of the ecological processes of oil's subterranean formation (Dukes 2003). In petroleum assemblages, the chemical effects of an ancient substance are linked to health and environmental damages (Sawyer 2015; Wylie 2018), also to bellicose nationalisms in the United States (Huber 2013; Mitchell 2011) and the world (Adkin 2016; Appel 2019; Coronil 1997; Karl 1997; Sawyer 2004; Watts 2004b, 2005). Petroleum underwrites capitalist affect (Bauman 2000; Deleuze and Guattari 1983) and is entangled with notions of geographic mobility (Appadurai 1996; Larkin 2013; Pinkus 2008; Seiler 2008). It has provisioned both American suburbia (Huber 2013; Rome 2001) and military power (Yergin 1990). The social and ecological toxicity integral to modern petroleum commodification is how I define petrotoxicity.

Broadly, pollution and toxicity are defined empirically and politically according to the socioecological conjunctures where they occur (Fortun 2001; Fortun and Fortun 2005; Little 2014; Murphy 2004; Petryna 2002). Petroleum's social and ecological toxicities seem ubiquitous, evidenced in industrial agriculture (Mitchell 2011; Romero 2016) and synthetic materials vital to modern humans (Bennett 2010; Chin 2001, 2016; Szeman and Boyer 2017). Climate science (Hansson 2017; Hulme 2009; Lennon 2020) and the chemistry of contamination (Hoover 2017; Murphy 2017; Sawyer 2015; Wylie 2018) are also sites where petrotoxicity is granted culturally specific meaning. Thinking about fossil fuels and climate change further highlights the petrotoxicity inherent in every push of a gas pedal (Masco 2017).

These notions suggest what petrotoxicity is intended to capture as an analytic: that petroleum is ecologically "intertwined with power relations understood as toxic" (Cielemecka and Asberg 2019: 102), power relations such as race, class, gender, and other remnants of coloniality (Hoover 2017; Lennon 2020; Nading 2020); and that the ecological toxicity of petroleum effectively provisions and powers the cultural practices that Matthew Huber calls our modern "fractionated lives" (2013: 61). An attention to petrotoxicity conveys how "oil underwrites modern [ecological] life but the social cost is addiction" (Appel et al. 2015: 11; see also Le Menager 2014). 
The modern environment is characterized by energy consumption (Guruswamy 2011; Pinkus 2016, 2017), which depends on settler colonialism's racialized and gendered hierarchies: this is only one of many links between North Dakota hydrocarbons and what scholars call global "petropolitics" (Mitchell 2011; Vitalis 2007). The lifestyles and technologies underwritten by petrotoxicity are inextricable from the phenomenology of a socioecologically damaged modern world (Nading 2020; Weston 2017).

For example, four cycles of oil's turbulent boom-bust economy have come and gone in northwestern North Dakota, leaving in their wake the empty temporary oilfield worker housing or "man camps" that I saw in the Bakken. A modern artifact of socioeconomic turbulence and a requirement of the oil industry's itinerant workforce (Caraher and Weber 2017), those camps are also an ominous threat to North American Native women (Lucchesi 2019; see also Estes 2019; and Whyte 2017). In essence, all "modern" (sensu Appadurai 1996) quotidian practices socioecologically depend upon petrotoxicity.

\section{The Petrotoxic Apparatus(es)}

The previous section reviewed literature framing petroleum-related toxicity as simultaneously social and ecological, and also constitutive of modern society. I argue in this section that the politics of petrotoxicity are often framed using an accurate but incomplete framing based in structural political economy and mirroring the Althusserian apparatus. (Sub)national analyses of the socioecological effects of petroleum tend to address the belligerent realm of political economic power relations (see Appel 2019; Coronil 1997; Estes 2019; Gill 2016; Huber 2013; Hughes 2017; Mitchell 2011; Rogers 2015; Sawyer 2004; and Shever 2012). And at both the national and international levels, research presents petrotoxicity as integral to the power of capital and/or government (Appel et al. 2015; Behrends et al. 2011; Karl 1997; Klare 2004; Ross 2015; Yergin 1990). That framing can be overly structural, essentializing the articulations of ecology, capitalism, and culture (Bear et al. 2015; Escobar 1999).

The tendency toward applying structural analysis of capital and government to the oil industry reflects the Marxist view that orients political ecology as an interdisciplinary field of inquiry (Escobar 1999; Greenberg and Park 1994; Peet et al. 2011), one heavily influenced by Watts's oil research (2004a, 2004b, 2005, 2008, 2012). When analyses of petroleum assemblages apply structural framings of the relationship between power, space, and populations under capitalist government, they frame petrotoxicity as something that very closely resembles Althusser's (1971) notion of the "apparatus."

Althusser describes apparatuses as assemblages of power, as material and abstract technologies wielded by government and capital over populations and spaces. Apparatuses manifest through ideologies, as well as repressive governance and onerous bureaucracies. They suggest and impose dictates that (re)generate the social relations of capital (Althusser 1971). Oil assemblages - unavoidable and inexorable in the modern world-have understandably been framed in ways that mirror the Althusserian apparatus, a framing that elucidates the mechanisms and outcomes of petrotoxicity.

For example, the DAPL was built to ship oil extracted in the Bakken. Doug Burgum-Stanford MBA, tech-millionaire, and North Dakota's governor-once told the press he expected the pipeline to be completed with the support of the federal government days before the Trump regime officially authorized the pipeline crossing at Lake Oahe (Scheyder 2017). The activists who I spoke to while at the Oceti Sakowin camp understood the multiscalar cooperation of capital and government to be generative of the pipeline; to be further evidence of continuing coloniality; 
and to be further evidence of the modern belief that natural resource exploitation can be ever more expansive and efficient (Ebron and Tsing 2017).

The requirements and effects of petroleum commodification are predicated on socioecological conditions at a particular extraction site (Adunbi 2013; Appel 2019; Bond 2013; Breglia 2013; Watts 2012); pipeline (Barry 2013; Estes 2019); refinery (Gill 2016; Valdivia 2017); or other less obvious manifestation of petroleum infrastructure and its attendant sociality, for example highways and suburbs (Huber 2013; Jobson 2018), or history and kinship groups (Rogers 2015; Shever 2012). DAPL was originally slated to go under the Missouri River north of Bismarck, upriver from the primarily White, urban state capital. Its residents, also local and state government, were displeased with that potential petrotoxicity and enlisted the US Army Corps of Engineers (USACE) to justify moving the underwater pipeline crossing to just upriver from the Standing Rock Reservation (Estes 2019; Estes and Dhillon 2019; Gilio-Whitaker 2019).

The stark inequalities between Bismarck and Standing Rock elucidated in the material history of the region and pipeline suggest how petrotoxicity can indeed seem to be an apparatus of America's racialized and gendered political economy. Althusser considered repressive and ideological apparatuses to be co-constitutive. The former impose social relations of production through governance and/or violence. Ideological apparatuses, on the other hand, foment the same social relations through subject-making, through the work of ideology and institutions in the material and abstract (Althusser 1971).

Since taking hold in the Americas in the mid-nineteenth century (Black 2000; Hughes 2017), commodification of petroleum generated petrotoxicity as well as cultural commitments to a modern hydrocarbon ecology (Mitchell 2011; Watts 2012). Anti-pipeline activists I came to know at the \#NoDAPL occupation depended on propane, gasoline, and automobiles for warmth and food, but were nonetheless committed to their cause. Paraphrasing Stuart Hall, ideologies are constituted by heartfelt practices that need not be clear or deeply theorized, and nonetheless "serve to condense and order the view of society in which the ideologies are active." Their acceptance as an "unquestioned substratum of truth" (Hall et al. 1978: 140) drives the emotional strength and political effect of ideologies.

That petrotoxicity - the socioecological toxicity inherent in petroleum commodificationwas simultaneously resisted and fomented at the \#NoDAPL camps is no evidence of a lack of commitment among activists. Instead, it reflects the pervasiveness of petroleum commodification and its socioecological toxicity in modern society. Even scholarship that claims an activist stance against the petroleum industry relies ecologically on social hierarchies maintained by petroleum-based travel, energy, and materials (Hughes 2017; Willow 2016; Wylie 2018). Petrotoxicity is imposed and embraced via abstract and material practices of government, capital, and subjects: all characteristics of an ideological apparatus.

The apparatus framing applied in scholarship and applicable to North Dakota politics neither exhaustively captures nor explains petrotoxicity. Thinking with Stuart Hall, this article concludes by suggesting that petrotoxicity is less cohesive and well-directed than implied by the paradigm of the apparatus. Thinking deeply about how modern humans resist and generate petrotoxicity suggests the limits of political and ecological analysis reliant on overly structural approaches to petroleum commodification and its socioecological toxicity.

\section{Petrotoxicity as Repressive Apparatus}

Environmental justice as a field of inquiry and praxis originated in Robert Bullard's (1993, 2000) analyses of racialized, repressive petrotoxicity in the American South (see also Bullard and Wright 2012). Governmental and corporate technologies and practices that impose toxic pet- 
rochemical pesticides in Martinique evidence petrotoxicity to be generated by, and generative of, colonial repression (Agard-Jones 2013). Analyzing bodily and environmental contamination from petrochemicals, scholars interrogate how colonial hierarchies of race (Estes 2019; Lennon 2020; Murphy 2004), class (Adkin 2016; Bond 2013; Gill 2016; Shever 2012; Wylie 2018), and gender (Appel 2019; Daggett 2018; Hoover 2017) are replicated in the quotidian practices of oil commodification: subsidiarization and modularity; corporate-governmental alliances; the production of expertise; as well as the alteration and obfuscation of scientific and historic facts.

By titling an analysis of African oil assemblages, in part, "Seeing Like an Oil Company"-an allusion to James Scott's (1998) work on the modernist state-James Ferguson (2005) suggests that there is a mutable boundary between oil companies and government, that both have the ability to project power toward sometimes-incommensurate ends. Failed promises of modernist development and/or environmental control based on petroleum, and the toxic outcomes of those failures: these are perennial concerns of scholarship on the oil industry (Appel 2019; Apter 2008; Breglia 2013; Coronil 1997; Gill 2016; Limbert 2010; Mason 2015; Sawyer 2004; Shever 2012). Repression via multiscalar petrotoxicity is a clear outcome of capitalist affect requiring petroleum for its realization (Daggett 2018; Deleuze and Guattari 1983; Huber 2013; Le Menager 2014).

Repressive apparatuses apply violence to maintain the social relations of capital (Althusser 1971), a political practice identified in various sites of petroleum commodification: extraction (Adunbi 2013; Appel 2019; Watts 2012); transportation (Estes 2019); refinement (Bullard 1993; Gill 2016; Misrach and Orff 2014; Valdivia 2017). Rather than always being enacted, such violence can also be merely implied as governments pursue political economic goals. Fernando Coronil's (1997) ethnohistory of the Venezuelan state, for example, elaborates how governments project power not with violent repression but instead with administrative apparatuses that define and direct natural resource usage in service of modern, nationalist aspirations and their attendant political economic hierarchies (see also Rogers 2015).

How similar processes unfolded across Venezuela and other twentieth-century petrostates is the subject of Terry Karl's (1997) resource curse work, which continues to shape scholarship on the political economic and governmental toxicity of the petroleum industry (Appel 2019; Obi 2010; Ross 2015; Watts 2004). Unconventional petroleum extraction methods like tar sands, deep water, and fracking gave rise to new terrestrial, subterranean, and chemical frontiers for the petroleum industry (Appel et al. 2015; Huber 2013; Watts 2012; Wylie 2018), frontiers where the tendencies that defined the resource curse continue to be empirically tractable and toxic. The unreflexive agglomeration of oil and capital can nonetheless lead to overlooking how oil assemblages are material and embodied, industrial and personal (Appel 2019; Appel et al. 2015; Rogers 2015; Shever 2012), and how that mutual constitution has always been fundamentally environmental (Le Menager 2014).

Nonetheless, tenets of the resource curse still hold in relation to petroleum: oil wealth still lends strength to authoritarian regimes; increases corruption; and also catalyzes conflict "in low- and middle-income countries, particularly when it is located in the territory of marginalized ethnic groups" (Ross 2015: 240). North Dakota shows some qualities of a petrostate: a low-to-middle-income polity with leadership unwavering in its commitment to fossil fuels and willing to engage in conflict with ethnically marginalized people to support that commitment: witness \#NoDAPL. But North Dakota is one state in a federal system with a privatized oil assemblage. That makes ascribing regional oil politics to the toxic effects of the resource curse a bit of a stretch in the Bakken.

Critiques of the resource curse highlight its limited attention to subnational dynamics and tendency to ascribe deterministic outcomes to the presence of natural resources, especially 
petroleum (Obi 2010; Weszkalnys 2011). In an analysis of transnational American oil companies, Appel (2019) adds that the resource curse paradigm offers a restrictive understanding of the social and material construction of oil capitalism, of the people and affects marshaled via petroleum assemblages in order to meet capital's demands.

Oil companies-especially state-owned ones-are widely considered syntheses of capital and government that project the ability to repress and/or conscript populations and space (Appel 2019; Coronil 1997; Ferguson 2005; Lu et al. 2017; Rogers 2015; Sawyer 2004; Shever 2012; Watts 2005; Wylie 2018). This understanding of the oil industry is indebted not only to political ecology, but more fundamentally to cultural analyses of extractive capitalism (Mintz 1985; Taussig 1980; Tsing 1994). That scholarship shows that petrotoxicity fits the criteria of the repressive apparatus: an assemblage of power applying violent and/or bureaucratic technologies in order to (re)generate political economic hierarchies. And just as they analyze repression via the modern petrotoxic apparatus, scholars also analyze its resistance.

In early February 2017, I got lost while looking for a place that sold propane in the small town of Fort Yates on the Standing Rock Reservation. I had offered to run the errand for people at the Oceti Sakowin camp who were trying to organize an event in the large geodesic dome that served as a camp meeting-place. The worst of the North Dakota winter had passed, but it was still cold. Propane was necessary if people were going to gather away from campfires and wood stoves.

Trying to locate the propane shop in Fort Yates, I walked up to one among a few clustered tribal government buildings, hoping to ask for directions. An older couple worked to move aluminum trays of food inside the building from their old minivan. I held the door, and the husband said I could join them for a meal if I was willing to help carry things inside. Nothing if not a diligent anthropologist, I helped and accepted the gift of lunch.

That building was the Standing Rock Sioux Tribe's Department of Water Resources. The older gentleman who offered me lunch turned out to be Dave Archambault, Sr., father of thenChairman of the Standing Rock Sioux Tribe, Dave Archambault, Jr. The elder Dave and his wife had prepared and delivered lunch to a team of experts that had gathered that day to discuss the tribal government's legal challenge to the expedited DAPL permits that were pushed through by the Trump regime via the USACE. An official tribal historian began the lunch with a story and prayer about the importance of sharing food and welcoming strangers as a cultural practice for Dakota, Nakota, and Lakota people, who refer to themselves as the Oceti Sakowin Oyate, the "People of the Seven Council Fires."

That team included lawyers, a biologist, and a pipeline expert, who all chatted with me amicably, and shared their business cards with me, which I did as well with them. Once lunch ended, the lead lawyer amicably asked me to leave given the sensitive nature of their conversation. The team's work came to fruition in July 2020, when a federal judge ruled that the USACE had rushed the permits, calling for the shutting down of the pipeline until the completion of a lengthy environmental review (that had been skipped by the Trump regime) (Fortin and Friedman 2020). That the pipeline, that petrotoxicity, was both permitted and challenged through governmentalized science evidences the ideological nature of such toxicity.

\section{Petrotoxicity as Repressive Apparatus}

Civil society, means of communication, and cultural artifacts can all be ideological apparatuses contributing to the social conditions of production (Althusser 1971). Ideological apparatuses function predominantly by inculcation and subject-making and "secondarily by repression," repression that can be attenuated and concealed, "even symbolic" (Althusser 1971:145). The 
sciences and the production of expertise figure saliently in Western ideological apparatuses (Foucault 1980).

Douglas Rogers's (2015) analysis of state/oil-company practices for producing hydrocarbons, memory, and history in Russia's Perm region is a clear example of thinking about petroleum commodification as, in part, an ideological apparatus: a material and abstract assemblage of power that shapes history, spatiality, and thereby sociality. Such an ideological apparatus generates petroleum-supporting subjects and spaces with near-ubiquity, a pervasiveness proving the imperfect separation of ideological and repressive petrotoxicity. How the petroleum-based shaping of space and history generates hydrocarbon-reliant subjects and spaces in ways redolent of repression has been studied in Trinidad and Tobago (Hughes 2017; Jobson 2018), Argentina (Shever 2012), Nigeria (Adunbi 2013), and the United States (Bond 2013; Huber 2013; Seiler 2008). Other research analyzes petrotoxic subject- and space-making as overtly violent repression (Gill 2016; Sawyer 2004; Silva 2018; Watts 2008).

Regardless of its toxic socioecological requirements and outcomes, petroleum is integral to modern environmental subjectivity (sensu Agrawal 2005; West 2006). Among people in favor of oil extraction, that subjectivity includes embracing oil capitalism while avoiding or mitigating its adverse social and ecological effects (Appel 2019; Bond 2013; Hughes 2017; Rogers 2015; Shever 2012; Wylie 2018). What petrotoxicity catalyzes and confounds became an object of global environmental politics and popular culture in the late 1960s.

An oil supertanker, the Torrey Canyon, crashed off of the coast of Cornwall, England, in 1967, highlighting for the world that modern government and industry depend on petroleum and therefore embrace the potential for petrotoxicity. Oil wells and oil tankers are both wellknown potential sources of petrotoxicity, as are well blowouts: when an unexpected volume of fluid-oil, gas, brine, drilling mud, and/or sea water-finds its way into a hydrocarbon wellbore, causing a spike in pressure released at the surface. In 1969, a well blowout caused an oil spill in California's Santa Barbara Channel, a spill that highlighted America's lack of preparedness for a petroleum catastrophe on its shores (Le Menager 2014).

Post-World War II America demonstrated a "pace-setting growth ethic" that shaped global modernity, an ethic reliant on a war economy and rhetoric that amounted to "a mission of intimate conquest, without and within" (Ebron and Tsing 2017: 663). This mission was powered and provisioned by petroleum (Huber 2013) and shipped around the world (Yergin 1990) via an oil industry that endeavored to transcend social, ecologic, and spatial contexts with practices of modularity integral to modern capitalism (Appel 2019). And just as the oil industry traveled based on war and rhetoric, on repression and ideology, so did American notions of capitalism and modernity and their environmental effects and their resistance (Ebron and Tsing 2017).

Petrotoxic apparatuses both generate and/or respond to conditions like blowouts, oil spills, and other forms of pollution. These apparatuses include petrochemical sciences (Hoover 2017; Huber 2013; Sawyer 2015); petroleum infrastructure and petroleum engineering (Appel 2019; Barry 2013; Black 2000; Boyer 2018); toxicology and environmental cleanup (Bond 2013; Hoover 2017; Fortun and Fortun 2005; Wylie 2018 ), and the mercurial world of oil finance (Mason 2015; Silverstein 2015; Weszkalnys 2015). All play a role in imposing petrotoxicity in ways experienced as repressive. All can also claim responsibility for its mitigation. That these apparatuses are unable and/or unwilling to eliminate petrotoxicity is proven by the fact that a well blowout also caused a more recent, globally recognized oil catastrophe: the Deepwater Horizon (Bond 2013; Watts 2012).

Rachel Carson's (2000 [1962]) exposé of a petroleum derivate-synthetic pesticides-is often credited with giving rise to the modern environmental movement. In the United States, the Santa Barbara oil spill also played a salient role by leading to the institution of the nation's early 
environmental regulations. But at the time of their implementation, enforcing those new regulations was difficult because "The U.S. Capitol floated on oil money-and middle-class environmental culture, too, would be suspended within a culture of oil" (Le Menager 2014: 23-24). Something similar is true of Deepwater Horizon (Bond 2013; Watts 2012) and, more generally, of legislation in relation to the US petrochemical industry (Huber 2013; Misrach and Orff 2014; Wylie 2018).

Petrotoxicity is experienced and potential, bodily and environmental, and it is often expressed through the ideological apparatuses of the sciences. And "the sciences and scientists are always on the move, changing in response to shifting contexts, always altering perspectives on what is real, natural, inevitable, possible, and obligatory" (Fortun and Fortun 2005: 50). Scholars of other extractive industries have also described the sciences as outgrowths of capitalism (Kirsch 2014; Li 2015). Rather than being defined by the essential qualities of either institution, science and capitalism arise and articulate according to the contexts of their practice (Escobar 1999).

Those practices include corporate and governmental technologies that occlude biophysical contamination and responsibility for cleanup. A common way of doing so is by redefining parameters of toxicity in the body (Hoover 2017; Sawyer 2015; Wylie 2018) and in terrestrial, aquatic, and climatic space (Bond 2013; Breglia 2013; Estes 2019; Hoover 2017; Hughes 2017; Hulme 2009; Sawyer 2015). Scholarship on the many facets of petrotoxicity shows how the dynamic intersections of science and capital generate, across diverse populations and spaces, the similar requirements and outcomes of petroleum commodification (Appel 2019; Bond 2013; Lennon 2020; Rogers 2015; Sawyer 2005; Watts 2012).

Thinking about petrotoxicity as repressive and ideological apparatuses, as structural mechanisms of power and knowledge, is a broad framing that reflects pronounced trends in literature/ arguments about petroleum commodification and its socioecological toxicity. Scholarship also includes recognition of how the nominal subjects of petrotoxic apparatuses can generate expertise and, based on that, practice counterpolitics that unsettle the power relationships presupposed by the analytic of the subject-making apparatuses.

Citizen science and its political deployment (Wylie 2018), addressing modern toxicity with Indigenous epistemologies (Hoover 2017), organizing for a shift to a green economy (Lennon 2020): these are a few examples of where the structural lens of the Althusserian apparatus falls short of capturing the empirical reality of petrotoxicity, particularly the reality that, despite the near-ubiquity of petroleum's toxic socioecological effects, there have always been people, spaces, and cultural practices that reveal the limits, the inconsistency, the incoherence of systems of power/knowledge and government based on petroleum.

Hall highlights the fragility and contingency of political economic power, the practices of self-determination, unaccounted for in Althusser. Concluding with Hall's take on ideology helps reframe petrotoxicity as more than a set of all-pervasive political economic and knowledge apparatuses. It also helps in thinking through a paradox that has become common sense in modern environmental politics: commitments to petroleum exist alongside concerns over petrotoxicity. Hall suggests the path toward a more capacious and nuanced understanding of what foments and what undermines petrotoxicity, elucidation that is much needed in the modern moment (Murphy 2017; Nading 2020).

\section{Beyond Apparatuses of Petrotoxicity}

When I arrived on a night in early February 2017, the Oceti Sakowin camp was lit by a nearly full moon and by large North Dakota Department of Transportation lights used by the horde 
of security forces a few hundred yards north of the camp. The ground was covered in ice. Dry cold air sapped warmth from my jeans, chilling me quickly despite my winter jacket. I asked a passing group of young people to point out Winona's kitchen, which I knew to be a semi-public space where I could warm up, lend a hand, and take the first steps toward shedding the menacing air that accompanies a lone male stranger who could be interpellated as White and arrives after dark in a space and among a people resisting coloniality.

I volunteered in Winona's for 13 days before the State of North Dakota shut down the camps on 22 February 2017. I spent most of my time organizing donations for the kitchen: sorting Chiapan coffee, Californian kale, and Vermont maple syrup; moving hundreds of pounds of canned goods and dried legumes, grains, and flours; and organizing crates of organic eggs and boxes of frozen sweet potato fries. The kitchen donations were generated by, and generative of, an expansive abstract and material network, a dynamic agglomeration of objects, individuals, and institutions with Winona at the helm.

The contents of the donation tent, the tent itself, were driven to the camp, which relied on propane for cooking and on gasoline for electric energy and for mobility. I slept in the camper of my pickup truck, kept warm by layers of synthetic materials. That modern paradox of petroleum commitment and concern was evidenced in the quotidian reliance on petroleum-based products and logistics shown at the \#NoDAPL occupation, a place born of a committed challenge to local and global manifestations of petrotoxicity. That paradox has a parallel in the Bakken, which is inhabited by people who identify as descendants of settlers committed to extractivism.

There, being in favor of oil extraction includes quotidian reliance on the oilfield for income from labor and/or from subsoil rents. That reliance does little to dampen the belief among many Bakken landowners that well-heeled industries-like some oil companies-and the local and state politicians overseeing them are in league with each other, and have historically operated without farmers' interests in mind (Lansing 2015). My research suggests that landowners of the Bakken shared with environmental activists the assumption that petrotoxicity is less an imposed condition than an incoherent and contestable one. The vast differences along coloniality's boundaries between the Bakken and Standing Rock make their respective practices of contestation also vastly different.

Hall wrote of Althusser's work: "He enabled me to live in and with difference" (1985: 92, emphasis in original). He did so because the French theorist elucidated political economy's structural qualities as variable, as repressive and/or ideological, material and/or abstract. But, the value of the "articulation of difference and unity" in Althusser, argues Hall, is diminished by Althusser's interpretation of repression and ideology, which narrows the relationship between government, capital, and subject down to the (re)construction of political economic structures like the colonial state (Hall 1985).

Hall's critique of Althusser starts with questioning the state as a driver of all cultural technologies and aspirations, as such overreliance leaves little room for the realm of contestation. The technologies, institutions, and beliefs that continuously undermine coloniality's racial and class hierarchies are more likely to go unseen when scholars overestimate the coherence and effectiveness of repressive and ideological apparatuses (Hall 1985). Granting political economic structures like states a deterministic ability occludes their incoherence (Ferguson and Gupta 2002). Hall's point is that highlighting such incoherence redefines social conditions, opening possibilities for novel politics.

The Santa Barbara oil spill and Standing Rock, for example, are distinct parts of a global history of challenging petrotoxicity. And contestation of petrotoxic apparatuses is a common theme in the literature on petroleum (Adkin 2016; Adunbi 2013; Breglia 2013; Gill 2016; Hoover 2017; Hughes 2017; Limbert 2010; Sawyer 2004; Willow 2016; Wylie 2018). In the US South, 
for example, the Deepwater Horizon disaster became a node of environmental organizing that revived concern about the toxicity of the region's numerous refineries and its petrochemical production industry (Bond 2013; Misrach and Orff 2014; Watts 2012).

Elizabeth Hoover (2017) links the bodily effects of a regional petrochemical industry to the colonial experiences of Haudenosaunee people living in the US Northeast and in southeastern Canada. Cultural history and a commitment to self-determination shaped responses to petrotoxicity among Hoover's interlocutors. They critically engage-neither wholly rejecting nor embracing-governmental and scientific institutions that can propagate biophysical contamination, that produce knowledge that minimizes the socioecological extent and consequences of petrochemical toxicity. Hoover (2017: 111) cites Peter Little, who describes industrial attempts to delimit both contamination and responses to it as "mitigation politics" (2014: 187), locating the origins of such politics in the articulations of government, capital, and science.

Community-based research practices like those in Hoover's work generate knowledge as a form of contestation, a practice studied in other petrotoxic contexts (Lennon 2020; Wylie 2018). At Standing Rock and among the Haudenosaunee Nation, people strategically deployed the "traditional"-roughly, precolonial and/or contemporary non-Western-approaches to nature/ culture (Escobar 1999) as an effective component of a praxis of science that challenges petrotoxicity and/or its mitigation politics (Estes and Dhillon 2019; Gilio-Whitaker 2019). Indigenous people in Latin America also apply similar strategies for contesting petrotoxicity (Bebbington and Bury 2013; Breglia 2013; Lu et al. 2017; Sawyer 2004), while Omoade Adunbi (2013) researches such strategies among Indigenous Nigerians.

Hall's relational paradigm for ideology, the "ideological field," transcends the notion of ideologies as discrete apparatuses. The racialized political economic structures that shaped his life as a Jamaican-born Brit, writes Hall, proved ideological apparatuses like race and capital to be only nominally coherent. In that flexibility, there was a possibility for orthodox ideologies to acquire new meaning, to be resignified. Blackness, in his case, gained new and subversive significance when considered part of a field of culture and meaning where toxic racial capitalism is always/ already undermined, even as it is (re)generated in the present (Hall 1985).

And this is how Hall offers a provocative path beyond thinking of petrotoxicity as apparatus(es). Petrotoxicity can be repressive: imposed violently or bureaucratically by political economic hierarchies capable of capturing the state. It can also be ideological: institutionalized in part through sciences and the social production of space. And petrotoxicity can also catalyze knowledge production and politics that unsettle existing arrangements of government and capital. Petrotoxicity is so variably defined in scholarship and experience that it serves as something of a floating signifier, a site where socioecological meaning is recreated, a site where power relations are renegotiated.

This is to say that apparatuses-the bureaucratic, subject-making, and potentially violent practices of capitalist government-are undoubtedly a relevant analytical lens for examining petrotoxicity. But, as Hall suggests of other hierarchical political ideologies, the apparatus is not coherent, exhaustive, or assiduously applicable. Petrotoxicity, the socioecological toxicity of petroleum commodification, is more than imposed and/or embraced apparatus(es). The Bakken and Standing Rock each-for profoundly different cultural reasons-evidence how petrotoxicity is continuously defined and redefined according to site and scale, to socioecological context, and to struggles for power.

Joseph Masco's (2017) work addressing the role of crisis in environmental politics suggests yet another set of framings used in literature/arguments on petrotoxicity. Government and the sciences address the existential problem of climate change with a sense of urgency, labeling it a "crisis." But turning to crisis as an analytic for the problem of climate change can result in an 
uncritical embrace of institutional framings of the problem, its potential victims, and its potential solutions (Masco 2017; Hughes 2017; Hulme 2009). Generally, defining a "crisis" precedes quickly defined interventions, giving both government and the public the impression that a problem has been adequately addressed via taskforces and committees, initiatives and foundations, even armies (Roitman 2013).

As a crisis, petrotoxicity is no longer a site of contestation. The petrotoxic "crisis" of climate change signals existential concern and sometimes-hasty solutions, some little more than a de facto call for a return to the political economic structures that created the problem, to new mitigation politics (Masco 2017). The same can be true of the politics and analytics of denouncing petroleum pollution (Fiske 2018; Lu et al. 2017). In that sense, the crisis narrative can function as precursor to corporate social responsibility and community investment practices that oil assemblages already use to mitigate petrotoxicity without having to eliminate it (Appel 2019; Bond 2013; Rogers 2015; Silva 2018).

Attending to contestation, oil scholarship tracks yet another outcome of petrotoxicity: revelation of the limits of repressive and/or ideological apparatuses as technologies of government. Considering "the commodity chain from hydrocarbons to hurricanes" to be "one unit" generated by lack of environmental conscience (Hughes 2017:4) - hydrocarbons as monolithic apparatuses imposing extraction and consumption on society-oversimplifies hydrocarbon ecology and politics. This article shows that the notion of a global, homogeneous, and toxic petroleum assemblage-a coherent petrotoxic apparatus-nonetheless figures saliently in understandings of petroleum's environmental politics.

Any modern staunchly opposed to petroleum inhabits nominally polar positions in the lexicon of the environment. Those positions are interconnected by the ecological experience of petroleum, forming what Hall referred to as a "unity in difference" (Hall et al. 1978: 168). Pro- and anti-petroleum political stances are limited explanatory frameworks that are shaped from broader ecological and cultural practices. Such explanatory frameworks function to return "shocking and random events" (Hall et al. 1978: 166) to a rational order of manageable things. Being pro- or anti-oil is an early step in attempting to manage petrotoxicity, though not necessarily in eliminating it.

The pro/anti framing contains "elements of explanation which are already available ... [and] have some relevance to the problem at hand." But such explanations are only "fragments of other, often earlier, more coherent and consistent theoretical elaborations which have lost their internal consistency over time, fragmented, become sedimented in ordinary 'common sense"' (Hall et al. 1978: 166). Modern humans opposed to petroleum are sedimented in economic and ecological common sense: oil is necessary and toxic. That common sense is the "skeletal syntax [of the environmental politics of petroleum], the elementary forms of the collective mental discourse of a great many ... people" (Hall et al. 1978: 169) when it comes to petrotoxicity.

I met an owner of land near Tioga, where a massive oil spill occurred. Early in our conversation, she sensed the environmentalist or anti-oil sentiments in some of my questions and asked me: "How did you get here?" For her, my reliance on the US petroleum assemblage did not invalidate my contestation of that assemblage, but it sure did complicate it. More than just chastising me, she called me into a shared responsibility for the oil spill cleanup on her farm.

In 2019, as the soil remediation came to an end there, the cleanup transitioned into an attempt to return the field to its once-productive condition, this using a new cover crop of rye and slender wheatgrass planted over what was once a vast pit created by the removal of polluted soil. Ninety-three million dollars turned the 75 -acre spill site back into what might become farmland again (Hageman 2019). There, petrotoxicity went from embodied and environmental, part of the local spatiality, back to the potential pollution found in pipelines and 
oil wells that are part of almost every farm in the Bakken. The same potential petrotoxicity lies in every gas tank.

The scientists, officials, corporate executives, and landowners who came together through scientific and political practice to remediate that spill outside Tioga effectively resignified petrotoxicity from a current and pressing problem into the background, from crisis into potential. And that is the last outcome of petrotoxicity discussed in this article: its conversion from socioecological reality and a tractable concern to environmental "white noise" (Murphy 2004). Petrotoxicity can be converted into a simple question of being pro- or anti-oil, while consumption continues unabated. Literature/arguments linked to petroleum consumption most clearly evidence the socioecological sites and scales, the fleeting moments and shrinking enclaves, where petrotoxicity becomes white noise.

Denouncing the petroleum industry and/or modern capitalism - for which petroleum commodification is a vital substrate-is an approach common to activism, scholarship, and activist scholarship (Estes and Dhillon 2017; Fiske 2018; Hughes 2017; Willow 2016; Wylie 2018), to studies of extractive industries (Kirsch 2014; Li 2015; Mintz 1985; Taussig 1980; Tsing 1994), and also to political economic approaches to the relationship between nature and ecology (Moore 2015). Such denunciation runs counter to scholarship that attends to the materiality of petroleum assemblages, scholarship labeling petroleum-based materials as being integral to modernity (Appel et al. 2015; Barry 2013; Huber 2013; Jobson 2018; Rogers 2015). The politics and analytics of denunciation overlook how petroleum consumption is a matter of culture and ecology (Masco 2017), which makes modern humans' denunciation of oil tantamount to a Trobriand Islander of a century ago denouncing coral.

Petroleum, toxicity included, is a socioecological requirement of modernity. That landowner in Tioga pointed out a common example of modern petroleum dependence-automobilitywhen asking me how I got to her farm. Mobility defines modernity (Appadurai 1996), while automobility has shaped US culture and geography since the mid-twentieth century (Huber 2013; Rome 2001; Seiler 2008). A related example of petroleum dependence, the fuels and pesticides that revolutionized the US and global food industry generated more extensive and intensive forms of agriculture, which in turn grew modern populations (Mitchell 2011; Romero 2016).

Pollution and toxicity are (re)generated via socioecological practices that persist, in part, because basic political frameworks like "pro/anti" shift ecological degradation into the realm of manageable problems. As is the case for all toxicity, petroleum-based commodities have biographies (sensu Kopytoff 1986) and form ecologies: processes that are not explained by denouncing them. Through petroleum's biography and ecology-from extraction to consumption, from disposable plastics to fossil fuels, global oil wars to extractive neocoloniality-petrotoxicity can be politically transformed into the experience of convenience and safety, mobility and comfort.

In a reflexive and insightful work on consumption, Elizabeth Chin writes the following about living in a household that made $\$ 90,000$ a year around 2016 , comparing that level of income to global averages: "It galls me to say it, but I am a member of an extremely tiny economic elite of enormous privilege and wealth. So are my students. So, perhaps, are you. Not feeling rich and elite does not mean it is not so" (2016: 6). Suggesting a socioecological parallel to Chin, that North Dakota landowner related my denunciation of petroleum to the petro-privileges that gall me to mention because I enjoy them: consuming petroleum-based energy and synthetics at will, and, more often than not, experiencing petrotoxicity as potential rather than actual.

To frame the socioecological toxicities of petroleum commodification in terms of being in favor or against them is to reiterate an ecological common sense as old as the American environmental movement, throughout which petroleum consumption increased as the issue of petro- 
toxicity was debated. Fossil fuel particulate pollution already contributes to millions of annual deaths (Vohra et al. 2021). In a few decades, hundreds of thousands will die each year because of climate change, deaths disproportionately concentrated among socioeconomically and racially marginalized people (Haines and Ebi 2019). Each ecological act of petroleum consumptionevery petro-privilege we moderns exercise-contributes to those deaths.

Thinking about that in light of recent world events suggests an intervention that might undermine these conditions. As COVID-19 ravaged the planet, a global economy dependent on petrotoxicity languished and the skies temporarily cleared over world cities with atmospheres known for being historically and visibly toxic (Gardiner 2020). The International Energy Administration recently suggested that a ban on new hydrocarbon extraction projects is needed to meet climate goals (Reed 2021). Although oil companies have long used calls for decreased consumption as a form of mitigation politics (Supran and Oreskes 2021), it seems clear that cutting consumption-especially where modern privileges allow-will alleviate some of the petroxicity that becomes a life and death issue for more people every day.

NÉSTOR L. SILVA is a PhD Candidate in the Department of Anthropology at Stanford University. His research in North Dakota's Bakken region examines how and why the people who engage in joint hydrocarbon production and agriculture-farmers and landowners, corporate executives and workers, scientists and government officials-practice environmental politics. He has conducted similar research on the environment and hydrocarbon industry in Latin America, and is co-author of Oil, Revolution, and Indigenous Citizenship in Ecuadorian Amazonia (Palgrave Macmillan, 2017).Email: nlsilva@stanford.edu

\section{REFERENCES}

Adkin, Laurie E., ed. 2016. First World Petro-Politics: The Political Ecology and Governance of Alberta. Toronto: University of Toronto Press.

Adunbi, Omoade. 2013. "Mythic Oil: Resources, Belonging, and the Politics of Claim Making among the Ilaje Yoruba of Nigeria." Africa 83 (2): 293-313. doi:10.1017/S0001972013000053.

Agard-Jones, Vanessa. 2013. “Bodies in the System.” Small Axe 17 (3 (42)): 182-192. doi:10.1215/ 07990537-2378991.

Agrawal, Arun. 2005. Environmentality: Technologies of Government and the Making of Subjects. Durham, NC: Duke University Press.

Althusser, Louis. 1971. Lenin and Philosophy and Other Essays. Trans. Ben Brewster. New York: Monthly Review Press.

Appadurai, Arjun. 1996. Modernity at Large: Cultural Dimensions of Globalization. Minneapolis: University of Minnesota Press.

Appel, Hannah. 2019. The Licit Life of Capitalism: US Oil in Equatorial Guinea. Durham, NC: Duke University Press.

Appel, Hannah, Arthur Mason, and Michael Watts, eds. 2015. Subterranean Estates: Life Worlds of Oil and Gas. Ithaca, NY: Cornell University Press.

Apter, Andrew H. 2008. The Pan-African Nation: Oil and the Spectacle of Culture in Nigeria. Chicago: University of Chicago Press.

Atutxa, Ibai. 2018. “Toxic Criminalities in Francoist Spain: The Making of a European Dictatorship.” $\mathrm{PhD}$ diss., Columbia University.

Barry, Andrew. 2013. Material Politics: Disputes along the Pipeline. Chichester, UK: Wiley-Blackwell.

Bauman, Zigmunt. 2000. Liquid Modernity. Cambridge: Polity Press. 
Bear, Laura, Karen Ho, Anna Lowenhaupt Tsing, and Sylvia Yanagisako. 2015. “Gens: A Feminist Manifesto for the Study of Capitalism." Fieldsights, 30 March. https://culanth.org/fieldsights/ gens-a-feminist-manifesto-for-the-study-of-capitalism.

Bebbington, Anthony and Jeffrey Bury. 2013. Subterranean Struggles: New Dynamic of Mining, Oil, and Gas in Latin America. Anthony Bebbington and Jeffrey Bury, eds. Austin: University of Texas Press.

Behrends, Andrea, Stephen P. Reyna, and Günther Schlee, eds. 2011. Crude Domination: An Anthropology of Oil. New York: Berghahn Books.

Bennett, Jane. 2010. Vibrant Matter: A Political Ecology of Things. Durham, NC: Duke University Press.

Bessire, Lucas, and David Bond. 2014. "Ontological Anthropology and the Deferral of Critique." American Ethnologist 41 (3): 440-456. doi:10.1111/amet.12083.

Black, Brian. 2000. Petrolia: The Landscape of America's First Oil Boom. Baltimore: Johns Hopkins University Press.

Bond, David. 2013. "Governing Disaster: The Political Life of the Environment during the BP Oil Spill." Cultural Anthropology 28 (4): 694-715. doi:10.1111/cuan.12033.

Boyer, Dominic. 2018. "Infrastructure, Potential Energy, Revolution." In The Promise of Infrastructure, ed. Nikhil Anand, Akhil Gupta, and Hannah Appel, 223-240. Durham, NC: Duke University Press.

Breglia, Lisa. 2013. Living with Oil: Promises, Peaks, and Declines on Mexico's Gulf Coast. Austin: University of Texas Press.

Bullard, Robert, ed. 1993. Confronting Environmental Racism: Voices from the Grassroots. Boston: South End Press.

Bullard, Robert. 2000. Dumping in Dixie: Race, Class and Environmental Quality. Boulder, CO: Westview Press.

Bullard, Robert, and Beverly Wright, eds. 2012. The Wrong Complexion for Protection: How the Government Response to Disaster Endangers African American Communities. New York: NYU Press.

Caraher, William R., and Bret A. Weber. 2017. The Bakken: An Archaeology of an Industrial Landscape. Fargo: North Dakota State University Press.

Carson, Rachel. (1962) 2000. Silent Spring. London: Penguin Classics.

Chin, Elizabeth. 2001. Purchasing Power: Black Kids and American Consumer Culture. Minneapolis: University of Minnesota Press.

Chin, Elizabeth. 2016. My Life with Things: The Consumer Diaries. Durham, NC: Duke University Press.

Cielemecka, Olga, and Cecilia Asberg. 2019. "Introduction: Toxic Embodiment and Feminist Environmental Humanities." Environmental Humanities 11 (1): 101-107. doi:10.1215/22011919-7349433.

Coronil, Fernando. 1997. The Magical State: Nature, Money, and Modernity in Venezuela. Chicago: University of Chicago Press.

Daggett, Cara. 2018. "Petro-Masculinity: Fossil Fuels and Authoritarian Desire." Millennium: Journal of International Studies 47 (1): 25-44. doi:10.1177/0305829818775817.

Dalrymple, Amy. 2017. "Burgum Challenges Oil Industry to Eliminate Spills, Increase Production." Grand Forks Herald, 18 July. https://www.grandforksherald.com/4299664-burgum-challengesoil-industry-eliminate-spills-increase-production.

Deleuze, Gilles, and Felix Guattari. 1983. Anti-Oedipus: Capitalism and Schizophrenia. Minneapolis: University of Minnesota Press.

Dukes, Jeffrey S. 2003. "Burning Buried Sunshine: Human Consumption of Ancient Solar Energy.” limate Change 61: 31-44. doi:10.1023/A:1026391317686.

Ebron, Paulla, and Anna Tsing. 2017. "Feminism and the Anthropocene: Assessing the Field through Recent Books." Feminist Studies 43 (3): 658-683. doi:10.15767/feministstudies.43.3.0658.

Escobar, Arturo. 1999. "After Nature: Steps to an Antiessentialist Political Ecology." Current Anthropology 40 (1): 1-30. doi:10.1086/515799.

Estes, Nick. 2019. Our History Is the Future: Standing Rock Versus the Dakota Access Pipeline, and the Long Tradition of Indigenous Resistance. London: Verso Books.

Estes, Nick, and Jaskiran Dhillon, eds. 2019. Standing with Standing Rock: Voices from the \#NoDAPL Movement. Minneapolis: University of Minnesota Press. 
Ferguson, James. 2005. “Seeing Like an Oil Company: Space, Security, and Global Capital in Neoliberal Africa." American Anthropologist 107 (3): 377-382. doi:10.1525/aa.2005.107.3.377.

Ferguson, James, and Akhil Gupta. 2002. "Spatializing States: Toward an Ethnography of Neoliberal Governmentality." American Ethnologist 29 (4): 981-1002. doi:10.1525/ae.2002.29.4.981.

Fiske, Amelia. 2018. "Dirty Hands: The Toxic Politics of Denunciation." Social Studies of Science 48 (3): 389-413.

Fortin, Jacey, and Lisa Friedman. 2020. "Dakota Access Pipeline to Shut Down Pending Review, Federal Judge Rules." New York Times, 6 July. https://www.nytimes.com/2020/07/06/us/dakota-access-pipe line.html.

Fortun, Kim. 2001. Advocacy after Bhopal: Environmentalism, Disaster, New Global Orders. Chicago: University of Chicago Press.

Fortun, Kim, and Mike Fortun. 2005. "Scientific Imaginaries and Ethical Plateaus in Contemporary U.S. Toxicology." American Anthropologist 107 (1): 43-54. doi:10.1525/aa.2005.107.1.043.

Foucault, Michel.1980. Power/Knowledge: Selected Interviews and Other Writings, 1972-1977. Ed. Colin Gordon. New York: Pantheon Books.

Gardiner, Beth. 2020. "Pollution made COVID-19 Worse: Now, Lockdowns Are Clearing the Air." National Geographic, 8 April. https://www.nationalgeographic.com/science/2020/04/pollutionmade-the-pandemic-worse-but-lockdowns-clean-the-sky/.

Gilio-Whitaker, Dina. 2019. As Long as Grass Grows: The Indigenous Fight for Environmental Justice from Colonization to Standing Rock. Boston: Beacon Press.

Gill, Lesley. 2016. A Century of Violence in a Red City: Popular Struggle, Counterinsurgency, and Human Rights in Colombia. Durham, NC: Duke University Press.

Greenberg, James B., and Thomas K. Park. 1994. "Political Ecology.” Journal of Political Ecology 1 (1): 1-12. doi:10.2458/v1i1.21154.

Guruswamy, Lakshman. 2011. "Energy Poverty." Annual Review of Environment and Resources 36: 139161. doi:10.1146/annurev-environ-040610-090118.

Hageman, John. 2019. "Nearly Six Years after Record Oil Spill, North Dakota Landowners See Work Ahead." Grand Forks Herald, 25 May. https://www.grandforksherald.com/news/government-andpolitics/1340862-Nearly-six-years-after-record-oil-spill-North-Dakota-landowners-see-workahead.

Haines, Andy, and Kristie Ebi. 2019. “The Imperative for Climate Action to Protect Health.” New England Journal of Medicine 380 (3): 263-273. doi:10.1056/NEJMra1807873.

Hall, Stuart. 1985. "Signification, Representation, Ideology: Althusser and the Post-Structuralist Debates." Critical Studies in Mass Communication 2 (2): 91-114. doi:10.1080/15295038509360070.

Hall, Stuart, Chas Critcher, Tony Jefferson, John Clarke, and Brian Roberts. 1978. Policing the Crisis: Mugging, the State, and Law and Order. London: The Macmillan Press Ltd.

Hansson, Sven Ove. 2017. "Science Denial as a Form of Pseudoscience." Studies in History and Philosophy of Science 63: 39-47. doi:10.1016/j.shpsa.2017.05.002.

Haraway, Donna J. 2016. Staying with the Trouble: Making Kin in the Chthulucene. Durham, NC: Duke University Press.

Hoover, Elizabeth. 2017. The River Is In Us: Fighting Toxics in a Mohawk Community. Minneapolis: University of Minnesota Press.

Huber, Matthew T. 2013. Lifeblood: Oil Freedom and the Forces of Capital. Minneapolis: University of Minnesota Press.

Hulme, Mike. 2009. Why We Disagree about Climate Change: Understanding Controversy, Inaction, and Opportunity. Cambridge: Cambridge University Press.

Hughes, David McDermott. 2017. Energy without Conscience: Oil, Climate Change, and Complicity. Durham, NC: Duke University Press.

Jobson, Ryan Cecil. 2018. "Road Work: Highways and Hegemony in Trinidad and Tobago." Journal of Latin American and Caribbean Anthropology 23 (3): 457-477. doi:10.1111/jlca.12345.

Karl, Terry Lynn. 1997. The Paradox of Plenty: Oil Booms and Petro-States. Berkeley: University of California Press. 
Kirsch, Stuart. 2014. Mining Capitalism: The Relationship between Corporations and Their Critics. Berkeley: University of California Press.

Klare, Michael T. 2004. Blood and Oil: The Dangers and Consequences of America's Growing Petroleum Dependency. New York: Metropolitan Books.

Kopytoff, Igor. 1986. "The Cultural Biography of Things: Commoditization as Process." In The Social Life of Things: Commodities in Cultural Perspective, ed. Arjun Appadurai, 64-95. Cambridge: Cambridge University Press.

Lansing, Michael J. 2015. Insurgent Democracy: The Nonpartisan League in North American Politics. Chicago: University of Chicago Press.

Larkin, Brian. 2013. "The Politics and Poetics of Infrastructure." Annual Review of Anthropology 42: 327-343. doi:10.1146/annurev-anthro-092412-155522.

Le Menager, Stephanie. 2014. Living Oil: Petroleum Culture in the American Century. New York: Oxford University Press.

Lennon, Myles. 2020. "Postcarbon Amnesia: Toward a Recognition of Racial Grief in Renewable Energy Futures." Science, Technology, \& Human Values 45 (5): 934-962. doi:10.1177/0162243919900556.

Li, Fabiana. 2015. Unearthing Conflict: Corporate Mining, Activism, and Expertise in Peru. Durham, NC: Duke University Press.

Limbert, Mandana E. 2010. In the Time of Oil: Piety, Memory, and Social Life in an Omani Town. Stanford, CA: Stanford University Press.

Little, Peter C. 2014. Toxic Town: IBM, Pollution, and Industrial Risks. New York: NYU Press.

Lu, Flora, Gabriela Valdivia, and Néstor L. Silva. 2017. Oil, Revolution, and Indigenous Citizenship in Ecuadorian Amazonia. New York: Palgrave Macmillan.

Lucchesi, Annita Hetoevèhotohke'e. 2019. "Mapping Geographies of Canadian Colonial Occupation: Pathway Analysis of Murdered Indigenous Women and Girls.” Gender, Place \& Culture 26 (6): 868887. doi:10.1080/0966369X.2018.1553864.

Masco, Joseph. 2017. “The Crisis in Crisis.” Current Anthropology 58 (S15): 65-76. doi:10.1086/688695.

Mason, Arthur. 2015. "Events Collectives: The Social Life of a Promise-Disappointment Cycle." In Subterranean Estates: Life Worlds of Oil and Gas, ed. Hannah Appel, Arthur Mason, and Michael Watts, 325-339. Ithaca, NY: Cornell University Press.

Mintz, Sidney W. 1985. Sweetness and Power: The Place of Sugar in Modern History. New York: Penguin Books.

Misrach, Richard, and Kate Orff. 2014. Petrochemical America. New York: Aperture.

Mitchell, Timothy. 2011. Carbon Democracy: Political Power in the Age of Oil. London: Verso Books.

Moore, Jason. 2015. Capitalism and the Web of Life: Ecology and the Accumulation of Capital. London: Verso Books

Murphy, Michelle. 2004. "Uncertain Exposures and the Privilege of Imperception: Activist Scientists and Race at the U.S. Environmental Protection Agency." Osiris, Landscapes of Exposure: Knowledge and Illness in Modern Environments 19: 266-282. https://www.jstor.org/stable/3655244.

Murphy, Michelle. 2017. "Alterlife and Decolonial Chemical Relations." Cultural Anthropology 32 (4): 494-503. doi:10.14506/ca32.4.02.

Nader, Laura, and Stephen Beckerman. 1978. "Energy as It Relates to the Quality and Style of Life." Annual Review of Energy 3: 1-28. doi:10.1146/annurev.eg.03.110178.000245.

Nading, Alex M. 2020. "Living in a Toxic World." Annual Review of Anthropology 49: 209-224. doi:10 .1146/annurev-anthro-010220-074557.

Obi, Cyril. 2010. "Oil as the 'Curse' of Conflict in Africa: Peering through the Smoke and Mirrors." Review of African Political Economy 37 (126): 483-495. doi:10.1080/03056244.2010.530947.

Peet, Richard, Paul Robbins, and Michael Watts, eds. 2011. Global Political Ecology. London: Routledge.

Petryna, Adriana. 2002. Life Exposed: Biological Citizens after Chernobyl. Princeton, NJ: Princeton University Press.

Pinkus, Karen. 2008. “On Climate, Cars, and Literary Theory.” Technology and Culture 49 (4): 10021009. https://www.jstor.org/stable/40061623.

Pinkus, Karen. 2016. Fuel: A Speculative Dictionary. Minneapolis: University of Minnesota. 
Pinkus, Karen. 2017. “Intermittent Grids.” South Atlantic Quarterly 116 (2): 327-343. doi:10.1215/ 00382876-3829434.

Reed, Stanley. 2021. “To Reach Climate Goals, New Oil and Gas Investments Must Be Stopped.” New York Times, May 18. https://www.nytimes.com/2021/05/18/business/climate-change-report.html.

Roberts, Elizabeth F. S. 2017. "What Gets Inside: Violent Entanglements and Toxic Boundaries in Mexico City." Cultural Anthropology 32 (4): 592-619. doi:10.14506/ca32.4.07.

Rogers, Douglas. 2015. The Depths of Russia: Oil, Power, and Culture after Socialism. Ithaca, NY: Cornell University Press.

Roitman, Janet L. 2013. Anti-Crisis. Durham, NC: Duke University Press.

Rome, Adam. 2001. The Bulldozer in the Countryside: Suburban Sprawl and the Rise of American Environmentalism. Cambridge: Cambridge University Press.

Romero, Adam M. 2016. “'From Oil Well to Farm': Industrial Waste, Shell Oil, and the Petrochemical Turn (1927-1947).” Agricultural History 90 (1): 70-93. doi:10.3098/ah.2016.090.1.70.

Ross, Michael. 2015. "What Have We Learned about the Resource Curse?" Annual Review of Political Science 18: 239-259. doi:10.1146/annurev-polisci-052213-040359.

Sawyer, Suzana. 2004. Crude Chronicles: Indigenous Politics, Multinational Oil, and Neoliberalism in Ecuador. Durham, NC: Duke University Press.

Sawyer, Suzana. 2015. "Crude Contamination: Law, Science, and Indeterminacy in Ecuador and Beyond." In Subterranean Estates: Life Worlds of Oil and Gas, ed. Hannah Appel, Arthur Mason, and Michael Watts, 126-146. Ithaca, NY: Cornell University Press.

Scheyder, Ernest. 2017. "New North Dakota Governor Expects Controversial Pipeline to Be Built." Reuters, 13 January. https://www.reuters.com/article/us-north-dakota-pipeline-burgumidUSKBN14X16L.

Scott, James. 1998. Seeing Like a State: How Certain Schemes to Improve the Human Condition Have Failed. New Haven, CT: Yale University Press.

Seiler, Cotton. 2008. Republic of Drivers: A Cultural History of Automobility in America. Chicago: University of Chicago Press.

Shever, Elana. 2012. Resources for Reform: Oil and Neoliberalism in Argentina. Stanford, CA: Stanford University Press.

Silva, Néstor L. 2018. “Jodidísimos’: The Local Politics of Hydrocarbon Acceptance in Colombia’s Eastern Plains." Journal of Latin American Geography 17 (3): 132-152. doi:10.1353/lag.2018.0044.

Silverstein, Ken. 2015. The Secret World of Oil. London: Verso Books.

Supran, Geoffrey, and Naomi Oreskes. 2021. "Rhetoric and Frame Analysis of ExxonMobil's Climate Change Communications.” One Earth 4 (5): 1-24. doi:10.1016/j.oneear.2021.04.014.

Szeman, Imre, and Dominic Boyer, eds. 2017. Energy Humanities: An Anthology. Baltimore: Johns Hopkins University Press.

Taussig, Michael T. 1980. The Devil and Commodity Fetishism in South America. Chapel Hill: University of North Carolina Press.

Tsing, Anna L. 1994. In the Realm of the Diamond Queen: Marginality in an Out-of-the-Way Place. Princeton, NJ: Princeton University Press.

Valdivia, Gabriela. 2017. “'Wagering Life' in the Petro-City: Embodied Ecologies of Oil Flow, Capitalism, and Justice in Esmeraldas, Ecuador." Annals of the American Association of Geographers. doi:10 $.1080 / 24694452.2017 .1369389$.

Vitalis, Robert. 2007. America's Kingdom: Mythmaking on the Saudi Oil Frontier. Redwood City, CA: Stanford University Press.

Vohra, Karn, Alina Vodonos, Joel Schwartz, Eloise A. Marais, Melissa P. Sulprizio, and Loretta J. Mickley. "Global Mortality from Outdoor Fine Particle Pollution Generated by Fossil Fuel Combustion: Results from GEOS-Chem.” Environmental Research 195: 1-8. doi:10.1016/j.envres.2021.110754.

Watts, Michael. 2004a. "Enclosure: A Modern Spatiality of Nature." In Envisioning Human Geographies, ed. Paul Cloke, Phillip Crang, and Mark Goodwin, 48-64. London: Routledge.

Watts, Michael. 2004b. "Resource Curse? Governmentality, Oil and Power in the Niger Delta, Nigeria." Geopolitics 9 (1): 50-80. doi:10.1080/14650040412331307832. 
Watts, Michael. 2005. "Righteous Oil? Human Rights, the Oil Complex, and Corporate Social Responsibility." Annual Review of Environmental Resources 30: 373-497. doi:0.1146/annurev.energy.30 .050504.144456.

Watts, Michael. 2008. The Curse of the Black Gold. New York: Powerhouse Press.

Watts, Michael. 2012. "A Tale of Two Gulfs: Life, Death, and Dispossession along Two Oil Frontiers." American Quarterly 64 (3): 437-467. https://www.jstor.org/stable/23273530.

West, Paige. 2006. Conservation Is Our Government Now: The Politics of Ecology in Papua New Guinea. Durham, NC: Duke University Press.

Weston, Kath. 2017. Animate Planet: Making Visceral Sense of Living in a High-Tech, Ecologically Damaged World. Durham, NC: Duke University Press.

Weszkalnys, Gisa. 2011. "Cursed Resources, or Articulations of Economic Theory in the Gulf of Guinea." Economy and Society 40 (3): 345-372. doi:10.1080/03085147.2011.580177.

Weszkalnys, Gisa. 2015. “Geology, Potentiality, Speculation: On the Indeterminacy of First Oil." Cultural Anthropology 30 (4): 611-639. doi:10.14506/ca30.4.08.

White, Leslie A. 1943. "Energy and the Evolution of Culture." American Anthropologist 45 (3): 335-356. doi:10.1525/aa.1943.45.3.02a00010.

Whyte, Kyle Powys. 2017. “The Dakota Access Pipeline, Environmental Injustice, and U.S. Colonialism.” Red Ink 19 (1): 154-159. https://www.thesilo.ca/wp-content/uploads/2017/02/The_Dakota_Access_ Pipeline_Environmental.pdf.

Willow, Anna. 2016. "Wells and Well-being: Neoliberalism and Holistic Sustainability in the Shale Energy Debate." Local Environment 21 (6): 768-788. doi:10.1080/13549839.2015.1017808.

Wylie, Sara Ann. 2018. Fractivism: Corporate Bodies and Chemical Bonds. Durham, NC: Duke University Press.

Yergin, Daniel. 1990. The Prize: The Epic Quest for Oil, Money \& Power. New York: Simon \& Schuster. 